2. Vetter HO, Burack JH, Factor SM, Malacuso F, Frater RWM. Replacement of chordae tendineae of the mitral valve using the new expanded PTFE suture in sheep. In: Bodnar E, Yacoub M, eds. Biologic and Bioprosthetic Valves. New York: Yorke Medical Books; 1986:772-85.

3. Salvador L, Mirone S, Bianchini, Regesta T, Patelli F, Minniti G, et al. A 20-year experience with mitral valve repair with artificial chordae in 608 patients. J Thorac Cardiovasc Surg. 2008;135:1280-7.
4. Perier P, Hohenberger W, Lakew F, Batz G, Urbanski P, Zacher M, et al. Toward a new paradigm for the reconstruction of posterior leaflet prolapse: midterm results of the "respect rather than resect" approach. Ann Thorac Surg. 2008;86: 718-25.

5. David TE, David CM, Lafreniere-Roula M, Manlhiot C. Long-term outcomes of chordal replacement with expanded polytetrafluoroethylene sutures to repair mitral leaflet prolapse. J Thorac Cardiovasc Surg. 2020;160:385-94.e1.
See Article page 385 .

\section{Commentary: Expanded polytetrafluoroethylene cordal implantation for mitral valve repair: The founder series}

\author{
James S. Gammie, MD
}

In this report of the long-term clinical and echocardiographic outcomes of 746 patients undergoing repair of degenerative mitral valve disease with expanded polytetrafluoroethylene (ePTFE) cordal repair techniques, David and colleagues provide compelling evidence of the effectiveness and long-term durability of ePTFE-based mitral valve repair. ${ }^{1}$ This series provides valuable information for the student of mitral valve repair. The completeness and duration of clinical and echocardiographic follow-up are outstanding: $97 \%$ and $83 \%$, respectively, with a median echocardiographic follow-up of 10 years. Key takeaways include the observations of good long-term freedom from recurrent mitral regurgitation (MR), with a 5\% risk of moderate or severe recurrent MR at 5 years and $10 \%$ at 15 years; a low risk of reoperation, with $1.3 \%$ at 5 years and $3.4 \%$ at 15 years; and that artificial cordal repair enables maximal repair rates.

It is notable that Dr David, a pioneering mitral valve repair surgeon with extensive clinical experience, has progressively increased the number of artificial ePTFE cords

\footnotetext{
From the Division of Cardiac Surgery, Department of Surgery, University of Maryland Medical Center, Baltimore, Md.

Disclosures: Dr Gammie serves as a consultant for Edwards Lifesciences.

Received for publication Oct 30, 2019; accepted for publication Oct 30, 2019; available ahead of print Nov 22, 2019.

Address for reprints: James S. Gammie, MD, Division of Cardiac Surgery, Department of Surgery, University of Maryland Medical Center, 110, S Paca St, 7th Floor, Room 7-S-190, Baltimore, MD 21201 (E-mail: jsgammiemd@gmail.com).

J Thorac Cardiovasc Surg 2020;160:397-8

$0022-5223 / \$ 36.00$

Copyright (c) 2019 by The American Association for Thoracic Surgery

https://doi.org/10.1016/j.jtcvs.2019.10.191
}

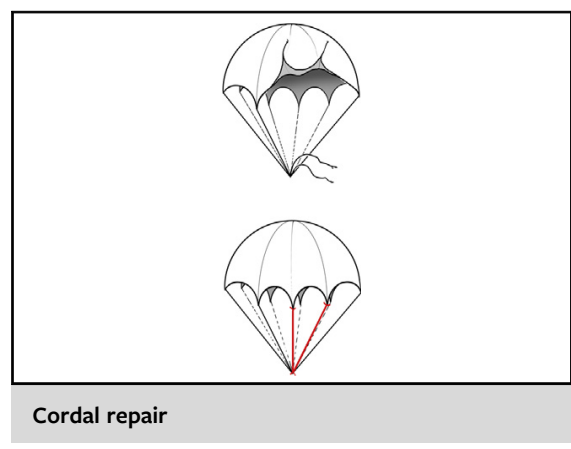

CENTRAL MESSAGE

Tirone David pioneered the use of ePTFE cords for mitral valve repair. The present series provides compelling evidence for the effectiveness and long-term durability of ePTFE-based mitral valve repair.

per case over time, from approximately 5 in the early years of this experience to 10 to 12 more recently. In fact, the overall median number of cords was 8 (or 4 pairs of cords), with implantation of 1 cord for each 2 to $3 \mathrm{~mm}$ of free leaflet edge. The "weaving" approach illustrated in the accompanying video enables the surgeon to efficiently implant a substantial number of cords and likely facilitates "autobalancing" of cordal segment lengths within a single suture. In the recent Society of Thoracic Surgeons adult cardiac surgery database experience, ePTFE cords were used in only one-third of repairs for degenerative leaflet prolapse, and among those patients undergoing ePTFE repairs, the median number of cordal pairs used was only $2 .^{2}$ It is likely that more cords are better than fewer cords.

The authors have identified isolated anterior leaflet prolapse as a risk factor for reoperation, as has been reported in other series. ${ }^{3}$ Precise cordal length adjustment and thus leaflet positioning is crucial to achieve adequate and 
durable coaptation in an anterior leaflet repair compared with a posterior leaflet repair, and this is a function of the anatomy of the mitral apparatus. There is a substantially greater margin of error in positioning the posterior leaflet. More reliable techniques for repair of degenerative anterior leaflet prolapse may offer the possibility of improving the durability of mitral valve repair. The authors report a significant late rate of atrial fibrillation and valve dysfunction, underscoring the importance of lifelong routine clinical and echocardiographic surveillance of patients after mitral valve repair.

Some key uncertainties in the use of ePTFE cords for mitral valve repair include whether concomitant resection is necessary in some cases. In this series, the authors used a combined resectional and artificial cordal approach in three-quarters of the patients. Others have published equivalent excellent results using a pure cordal replacement strategy without resection. ${ }^{4,5}$ A purely nonresectional approach may have the benefit of simplifying mitral repairs for the less experienced mitral valve surgeon by decreasing the number of variables to consider in planning repair. The need for leaflet reattachment and repositioning in instances of mitral annular disjunction is also unclear and not widely practiced.

Finally, it is notable that the Toronto Ethics Board is now requiring written consent from patients for follow-up in a retrospective observational series. This is an example of regulatory overreach that will have an important adverse effect on clinical research. Dr David is a pioneer in the use of ePTFE for mitral valve repair, and surgeons worldwide have learned and continue to learn from this founder's experience. To mandate written informed patient consent for a retrospective clinical study is not realistic and will yield incomplete observation and preclude a full understanding of the late results of an important operative technique. Retrospective observational trials such as this fall squarely into the category of minimal risk clinical research and remain an important means for surgeons and their patients to adequately evaluate an operative intervention.

\section{References}

1. David TE, David CM, Lafreniere-Roula M, Manlhiot C. Long-term outcomes of chordal replacement with expanded polytetrafluoroethylene sutures to repair mitral leaflet prolapse. J Thorac Cardiovasc Surg. 2020;160: 385-94.e1.

2. Gammie JS, Chikwe J, Badhwar V, Thibault DP, Vemulapalli S, Thourani VH, et al. Isolated mitral valve surgery: the Society of Thoracic Surgeons adult cardiac surgery database analysis. Ann Thorac Surg. 2018;106:716-27.

3. Suri RM, Schaff HV, Dearani JA, Sundt TA III, Daly RC, Mullany CJ, et al. Survival advantage and improved durability of mitral repair for leaflet prolapse subsets in the current era. Ann Thorac Surg. 2006;82:819-27.

4. Lawrie GM, Earle EA, Earle N. Intermediate-term results of a nonresectional dynamic repair technique in 662 patients with mitral valve prolapse and mitral regurgitation. J Thorac Cardiovasc Surg. 2011;141:368-76.

5. Pasrija C, Tran D, Ghoreishi M, Kotloff E, Yim D, Finkel J, et al. Degenerative mitral valve repair simplified: an evolution to universal artificial cordal repair. Ann Thorac Surg. December 18, 2019 [In press]. 